\title{
Bacterial Community Profiles in the Fluid of Four Pitcher Plant Species (Nepenthes spp.) Grown in a Nursery
}

\author{
ANDREE SIEGARA AND YOGIARA* \\ School of Biotechnology, Universitas Katolik Indonesia Atma Jaya, \\ Jalan Jenderal Sudirman 51, Jakarta 12930, Indonesia
}

\begin{abstract}
Nepenthes is one of the Indonesian tropical carnivorous plants. The plant has a pitcher-like structure containing fluid for digesting insects. There are many microorganisms growing in the pitcher fluid. Different species of pitcher plants and planting sites could also contribute either to the diversity or the abundance of microorganism inhabiting the pitcher fluid. To assess the bacterial community variation in the fluid of pitcher plants grown in a nursery, amplified ribosomal DNA restriction analysis (ARDRA) was used. Four specimens of $N$. gracilis, $N$. truncata, $N$. veitchii and $N$. bicalcarata were obtained from Suska Nursery, Ciderum Village, Caringin, Bogor, Indonesia. A total of 191 positive clones were analyzed by using ARDRA. A sum of 124 phylotypes was obtained, comprising 17 in $N$. gracilis, 7 in $N$. truncata, 45 in N. veitchii and 55 in $N$. bicalcarata. It is interesting to note that each specimen harbored unique phylotypes, meaning that no phylotypes generated from one specimen were found in any of other specimens.
\end{abstract}

Key words: Nepenthes, nursery, bacterial community, ARDRA

The pitcher plant (Nepenthes spp.) is one of the tropical carnivorous plants of Indonesia. The leaves of Nepenthes species are highly specialized. The 'leaf blade' bears at its tip a tendril, from which arises a sharply upturned and hollow pitcher, with a more or less oblique mouth overhung by a lid, from the base of which arises a short spur. The plant has two types of pitcher, upper pitcher and lower pitcher. These two types of pitcher contain fluid of the plant's own production. The pitcher acts as a pitfall trap for a wide range of invertebrates and, less commonly, vertebrates (Cheek and Jebb 2001). Many small animals might be trapped in the pitcher, the fluid contained therein becomes a suitable habitat for microorganism growth.

The plant secretes degradative enzymes, including ribonucleases, phosphatases (Matthews 1960), proteinases (Nepenthesins I and II) (Hatano and Hamada 2008) and possibly chitinases (Amagase 1972) as well as ions including chloride (Luttge 1971) and calcium (Massa 1998). These enzymes help the plant to digest preys. Up to $70 \%$ of the total nitrogen needed by a plant is provided by the digestion of the prey. Beside those enzymes, all Nepenthes species produce also various chemical substances, such as naphthoquinones, known as a substance having an antimalarial property (Rizzacasa and Sargent 1987).

To date there are very few publications on microbial community diversity in Nepenthes. Yogiara et al. (2006) collected fluid samples from several pitcher plants from various locations and found 16-39 groups of bacteria lived inside the pitchers. The bacterial community profiles were different from one specimen to the others. As yet there were no publications clearly clarifying whether the community development was affected by its local environment (habitat) or the fluid. The succession of microbial population inside the fluid has not been known properly. Based on the result of his research, Yogiara et al. (2006) proposed that the growth of microorganisms might have not been affected by the

*Corresponding author: Phone: +62-21-5703306 ext.449, Fax: +62-21-5719060, E-mail: yogiara@atmajaya.ac.id locations or habitats, where the pitcher plants are grown, but could have been more affected by the chemical substances released in the fluid and simultaneously developed during pitcher's lid opening.

The objectives of the present study are (i) to investigate a correlation between habitat and microbial community composition in pitchers of plant grown in a nursery, (ii) to obtain information on bacterial diversity and (iii) to gain bacterial community comparison in four pitcher fluid samples from different species of pitcher plants.

\section{MATERIALS AND METHOD}

Fluid Sampling and DNA Extraction. Pitcher plant specimens were obtained from Suska Nursery in Ciderum village, Caringin, Bogor-Indonesia. About 10-25 mL of fluid collected from several pitchers was poured into centrifuge tubes. To reach that sufficient volume we had to collect the fluid from several pitchers, because each pitcher can only provide about 1-5 mL of fluid. The origin and the scientific names of species, $\mathrm{pH}$ and types of pitchers were recorded. Collected samples were then kept in an ice box to minimize the changes of community composition during the transportation to the laboratory. Bacterial DNA in pitcher plant fluid was extracted using FastDNA ${ }^{\circledR}$ SPIN Kit for Soil (Qbiogen, USA).

Construction of 16S-rRNA Gene Libraries. 16S-rRNA gene was amplified using bacterial universal primers, 63f (5'CAG GCC TAA CAC ATG CAA GTC-3') and 1387r (5'-GGG CGG WGT GTA CAA GGC-3') (Marchesi et al. 1998). The PCR master mix consisted of 5 pmol of each primer, $200 \mu \mathrm{M}$ dNTP, 1x Taq polymerase buffer, $2.5 \mathrm{U}$ of Taq polymerase, $1 \mu \mathrm{L}$ of template and $\mathrm{ddH}_{2} \mathrm{O}$ up to a final volume of $25 \mu \mathrm{L}$. The amplification process was done using PCR GeneAmp ${ }^{\circledR}$ PCR system 2400 (Perkin-Elmer Co., Norwalk, Conn). The following cycles used were $94^{\circ} \mathrm{C}$ for 2 min then followed by 30 cycles at $94^{\circ} \mathrm{C}$ for $1 \mathrm{~min}, 55^{\circ} \mathrm{C}$ for $30 \mathrm{sec}$ and $72^{\circ} \mathrm{C}$ for $1 \mathrm{~min}$. The extension was completed at $72^{\circ} \mathrm{C}$ for 20 min after 30 cycles, and was held at $4{ }^{\circ} \mathrm{C}$ until further use. The PCR products 